\title{
The Influence of Geographical Coverage on the Microfinance Sustainability and Outreach in Northern Ghana
}

\author{
Issahaku Salifu ${ }^{1}$ \\ ${ }^{1}$ Faculty of Business, Accounting Department, Tamale Technical University, Tamale, Ghana \\ Correspondence: Issahaku Salifu, Faculty of Business, Accounting Department, Tamale Technical University, \\ Tamale, Ghana. P. O. Box 3 E/R, Ghana. E-mail: isalifu@tatu.edu.gh
}

Received: November 28, 2019

Accepted: January 8, 2019

Online Published: January 30, 2020

doi:10.5539/ijef.v12n2p82

URL: https://doi.org/10.5539/ijef.v12n2p82

\begin{abstract}
The study examined for statistically significant relationship between geographical coverage of microfinance institutions and sustainability and outreach from the view point of managers and operational staff in northern Ghana. Structured questionnaire was used in collecting data. The questionnaire was administered to a sample of 181 managers and operational staff of 18 microfinance institutions. The study used primary data. In selecting the respondents for this research paper, purposive and convenient sampling techniques were employed. The questionnaire was personally administered by the researcher. The study was conducted to ethical standards and respondents were made aware that participating in the study was voluntary. Data collected was analyzed using Spearman's correlation and descriptive statistics. The research uncovered a statistically significant positive relationship between geographical coverage and sustainability and outreach in northern Ghana using Spearman's correlation. In addition, the use of descriptive statistics showed that geographical coverage of microfinance institution influenced its sustainability and outreach with particular reference to the number of clients served, location of offices or branches, and scope of coverage. This study adds to the literature on geographical coverage and microfinance sustainability and outreach in the context of northern Ghana. This study is limited to only northern Ghana and not Ghana in its entirety.
\end{abstract}

Keywords: Ghana, microfinance institutions, outreach, sustainability, geographical coverage

\section{Introduction}

The practical problem in northern Ghana is the lack of access to credit from the main traditional banks by the poor. The high poverty incidence in northern Ghana perhaps is largely the cause of this problem. This gap in access to credit by the poor is filled by microfinance institutions. However, most of the microfinance institutions are not located close to the poor in order to reach the poor at a lower cost. Many of the microfinance firms, in fact, have their offices located in cities. As a result, it is expensive for Microfinance Institutions (MFIs) to identify and serve poor clients around the world especially in Ghana as the process involves high transaction costs and risk with associated lower expected returns. Microfinance is certainly not a new phenomenon the world over since it has been one of many effective tools used for fighting poverty by governments around the globe, and in particular developing economies. As a result, in the international microfinance arena, there are two related terms often used to explain the concept of microfinance. These terms are microcredit and microfinance.

On the one hand, microcredit involves granting of small amount of loans to clients in order for them to undertake economic activity in return for interest income by Microfinance Institutions (MFIs). On the other hand, microfinance involves not just the granting of loans to the productive poor, it also includes the rendering of micro services such as savings, insurance, fund transfer services, among others, by MFIs in return for an interest income. These institutions make loans available to borrowers who seek relatively small amounts and who may be viewed as too risky by larger conventional lenders. Although microfinance operations have seen considerable growth in recent years (Demirguc-Kunt \& Klapper, 2012), the potential market of such an activity is still below the actual needs to finance small projects and people under financial necessity (Nurmakhanova, Kretzschmar, \& Fedhila, 2015).

Microfinance is an effective tool to fight poverty by providing financial services to those who do not have access to credit or are neglected by the commercial banks and other financial institutions (Dokulilova et al., 2009). Different scholars have defined microfinance institutions in different ways. The essence of the definition, however, 
is usually the same in which microfinance is referred to the granting of financial services, mainly saving and credit to the productive poor clients (Legerwood, 1999).

Microfinance as small scale financial services - primarily credit and saving provided to people who farm or fish or herd, who operate small enterprises or micro enterprises where goods are produced, recycled, repaired, or sold, who provide services, who work for wages or commissions; who gain income from renting out small amounts of land, vehicles, draft animals, or machinery and tools; and to other individuals and groups at the local levels of developing countries, both rural and urban (Tehulu, 2013).

It must be emphasized that MFIs do not provide their financial services to the poor clients for free, which in most cases is not explicitly mentioned in the literature (Omondi, 2014). The poor actually pay at very high interest rates. To this end, microfinance is the provision of financial services to low-income clients who traditionally lacked access to banking and related services. The financial services include not just credit but also savings, insurance, and fund transfers. Microcredit is the provision of credit services to poor clients. In this sense, microfinance is a broad category of services, which includes microcredit. Microfinance has become a global critical topic in the academia and practice because of the important role microfinance plays in poverty reduction (Milana \& Ashta, 2012; Britzelmaier, Kraus, \& Xu, 2013).

Microfinance is the provision of a broad range of financial services to low-income micro enterprises and households. The range of financial services usually includes savings, loans, insurance, leasing, money transfers, and others. Microcredit emphasizes the provision of credit services to low income clients, usually in the form of small loans for micro enterprise and income generating activities (Bakhtiari, 2006). It is thus important to note that the use of the term 'microcredit' according to Bakhtiari (2006) is often associated with an inadequate amount of the value of savings for the poor. In most cases, the provision of savings services in 'microcredit' schemes simply involves the collection of compulsory deposit amounts that are designed only to collateralize those loans. Additional voluntary savings may be collected but the clients have restricted access to their enforced savings.

These savings become the main source of capital in the financial institutions. It is against this backdrop that in recent times, sustainability has been the biggest concern for stakeholders in the microfinance industry around the globe. Britzelmaier, Kraus, and Xu (2013, p. 67) indicate that "the essence of microfinance is to draw ideas from existing informal sector credit mechanisms - like intra-family loans in order to provide financial resources to the poor population". In fact, they argue that informal capital is an important factor in financing in countries characterized by an undeveloped financial system. In modern literature on microfinance, Mohammed Yunus has been credited as the father of microfinance by some researchers due to the establishment of the Grameen bank in Bangladesh.

In Ghana, outreach to the poor has been limited to urban areas and MFIs end up actually serving the marginally poor clients due to their profit motives rather than poverty alleviation. Instead of MFIs locating their offices in rural areas where they can easily reach the productive poor at a relatively lower costs most of them end up operating in major cities thereby serving the rich people or the marginally poor clients. This paper therefore seeks to examine the extent to which geographical coverage of an MFI influence the sustainability and outreach of MFIs in northern Ghana. The study therefore contributes to knowledge globally, and Ghana in particular on the sustainability and outreach of MFIs in their effort to reducing poverty among poor clients.

The principal objective of this research paper is to assess for relationship between geographical coverage of microfinance institutions and their sustainability and outreach in northern Ghana. The research question is there a relationship between geographical coverage of microfinance institutions and their sustainability and outreach in northern Ghana?

\subsection{Research Hypothesis}

H1a: There is a relationship between geographical coverage of microfinance institutions and their sustainability and outreach in northern Ghana.

The rest of the paper proceeds in four parts. Section 2 reviews theoretical framework and related literature; Section 3 discusses the research methodology; Section 4 presents and discusses the result of the study; and Section 5 presents the conclusions and recommendations.

\section{Theoretical Framework and Literature Review}

This section of the paper looked at the theoretical background and related empirical review underpinning this study.

\subsection{Grameen Model Theory}

Professor Muhammad Yunus, the founder and Managing Director of Grameen Bank, invented the Grameen model 
in 1976. The model proved to be successful and today is practiced in more than 250 outlets of Grameen Bank in more than 100 countries (Yunus, 1999; Bayar, 2013). The Grameen model was copied, modified, and replicated many times according to the respective needs of regional markets and clients the world over. As a result, many other models are extensions of, or derived from, the Grameen Model (Omondi, 2014; Bayar, 2013).

A practical application of this model involves the establishment of a new village MFI with field officers and some qualified workers. However, before the establishment of the new MFI the field officers and the workers would have conducted a study relating to the potential demand for financial support on the population well in advance. These employees of the MFI support up to 15 to 20 villages in the local community and strive to make the local poor people aware of the microfinance possibilities by face-to-face interaction and interpersonal communication. The lending process is similar to the solidarity group approach and as such, groups of five are created for financial support (Omondi, 2014).

From the start of the lending process, only two members of the group receive a loan and are monitored for one month by the MFI. The credibility of the group will then be based on the repayment performance of the first two individuals to whom the loan is given (Bayar, 2013; Aveh, 2011). If the initial two borrowers are reliable and are able to pay back their loan in good time, the remaining members qualify for a loan as well, since the group is jointly and severally liable for the individual members (Omondi, 2014). Consequently, the loans go first to two members of the group, then to another two, and then to the fifth member of the group and that provided the loans are being correctly and timely repaid, the cycle of lending continues (Armendáriz \& Morduch, 2005, as cited in Omondi, 2014).

\subsection{Group Lending/Joint Liability}

Group lending theory is based on group peer pressure whereby credits are extended to individuals in small group members of four to seven (Yunus, 1999). Group lending refers specifically to arrangements by individuals without collateral who get together and form groups with the aim of obtaining loans from a lender or MFI. A special feature of group lending is that the loans are made available individually to group members. However, all members in the group face the consequences if any member runs into serious repayment difficulties (Aveh, 2011). As a result, group members collectively guarantee loan repayment, and access to future loan is largely dependent on successful repayment by all group members.

Madajewicz (2011) further demonstrates that borrowers are able to monitor each other when liability is joint, while MFIs monitors borrowers on standard debt contract. Joint liability therefore offers poorer borrowers' larger loans with less monitoring effort than would have been exerted by the lender. Less monitoring on the part of the MFI and larger loan sizes is likely to enhance MFI performance and sustainability (Omondi, 2014). Similarly, Becchetti and Conzo (2011) and Jeon and Menicucci (2010) indicate that group lending dominates individual lending either by providing more insurance or by saving audit costs. All these merits of group lending therefore have implications on MFIs profitability, outreach and sustainability.

\subsection{Trade-Off Theory}

The trade-off theory posits that MFIs must meet financial and social goals simultaneously and this is referred to in the microfinance literature as double bottom line. Leikem (2012) indicates that the double bottom line approach is where MFIs must trade-off social performance (including poverty reduction) and financial performance (growth and potential future capacity) or find innovative ways to do both at the same time.

Myers as cited in Omondi (2014) contends that the tradeoff theory justifies moderate debt ratios. It says that the firm will borrow up to the point where the marginal value of tax shields on additional debt is offset by the increase in the present value of possible costs of financial distress. Financial distress refers to the costs of bankruptcy or reorganization, and also to the agency costs that arise when the firm's creditworthiness is in doubt (Omondi, 2014).

\subsection{Financial Sustainability}

For a microfinance institution to be sustainable in its operations, it should be able to generate sufficient revenue in order to cover its operational costs. Sustainability means the ability of an MFI to continue its operations successfully without any difficulty. In other words, sustainability refers to the ability of an MFI to cover its operating costs from its operating revenues so that the MFI is able to survive and prosper in the long run (Britzelmaier, Kraus, \& Xu, 2013). In this regard, for sustainable poverty alleviation, the MFIs themselves should be sustainable, since unsustainable MFIs will not help the poor in the future because the MFIs will be gone (Schreiner, 2002; Nyamsogoro, 2010; Tuluhu, 2013; Kinde, 2012).

The positive impacts of MFIs on the socio-economic welfare of the poor can only be sustained if the institutions can achieve a good financial and outreach performance. Throughout the world, financial sustainability of 
microfinance institutions has been one of the issues that have recently captured the attention of many researchers due to its importance in the existence of microfinance institutions (Kinde, 2012). Ganka (2010) argues that it may be better not to have MFIs than having unsustainable MFIs. This shows how indispensable the sustainability of MFIs is, and studying factors that affect sustainability of MFIs and how MFIs can become financially sustainable becomes imperative (Kinde, 2012). In this regard, the study is designed to determine the factors affecting the financial sustainability and outreach of MFIs in northern Ghana where the level of poverty is wide and deep.

Microfinance sustainability has several dimensions including programme sustainability, financial sustainability, human resource sustainability, and mission sustainability. The programme sustainability refers to microfinance products and services that are innovative and meet customer requirements because the clients consider these products and services very important and will continue to patronize them into the foreseeable future. Financial sustainability refers to the ability of microfinance institutions to generate enough revenues from their operations in order to cover all of their cost of operations. Human resource sustainability is the aspect of sustainability which measures the requisite qualifications of staff in the provision and delivery of microfinance services and products to the poor. The staff must be qualified, innovative, properly remunerated, and committed to the cause of working to improve social welfare among the poor. Finally, microfinance institutions must continue to working in order to advance the objective for which they were established, that is to promote the social welfare of the productive poor on a continuous basis without drifting or diversifying into areas which originally were not part of their mission at the point of their establishment.

\subsection{Outreach of Microfinance Institutions}

If MFIs are to make a significant impact in the attempt to reduce world poverty and in a developing country like Ghana, they have to serve a large number of the productive poor people, including women borrowers in both rural and urban areas on a sustained manner or an on-going basis. Outreach refers to the number of clients served (Kyereboah-Coleman, 2007). Outreach is an important aspect of microfinance in view of the fact that the fundamental aim of microfinance is to reach out to many unserved poor people who do not have access to financial services. Limited outreach can influence the sustainability in terms of benefits linked to economies of scale (Mulunga, 2010). Schreiner (2002) provides somewhat more comprehensive definition of outreach and proposed outreach has six dimensions, namely; worth of outreach, cost of outreach, scope of outreach, depth of outreach, length of outreach, and breadth of outreach. Similarly, other factors that affect outreach of MFIs include the size, capital structure, ownership structure, and age of the MFIs.

Breadth of outreach is measured by the number of people an MFI has extended credit to, or the number of borrowers over a specific period of time (Quayes, 2012). Breadth of outreach refers to the number of productive poor served by a microfinance institution (Kinde, 2012). A number of studies, including (Ganka, 2010; Mersland \& Strom, 2009; Harmes et al., 2008) have used the number of borrowers as a measure of MFIs breadth of outreach. Generally, the assumption in the microcredit industry is that the larger the number of borrowers the better the outreach to reducing poverty among the productive poor in communities in developing countries including Ghana, and northern Ghana in particular.

Depth of outreach is defined as access of credit disbursement to poor people; wherein the poorer the borrowers are the greater the depth of outreach (Quayes, 2012). Breadth of outreach could be misleading because an MFI may have a number of clients but the very poor may form a smaller proportion of total borrowers. Additionally, without the poor the supposed MFI is no longer different from a traditional commercial bank and as such, MFIs must make conscious effort in reaching the very poor for which the ideology of microfinance thrives. As a result, Hulme and Musley (1996) argue that just total number of clients should not measure outreach but instead it should rather be based on the number of poor clients.

Measuring outreach to the productive poor is mainly centered on breadth and depth of outreach. While determining outreach to the poor, MFIs must be careful as they may extend credit and services to many clients who may not necessarily be the poor people. Breadth of outreach could be misleading, and therefore, extending credit to as many poor clients as possible for which MFIs were established is referred to as depth of outreach and that is what should be focused on to achieving outreach rather that breadth of outreach.

\subsection{Capital Structure, Financial Sustainability and Outreach of MFIs}

A well-established MFI with an appropriate mix of capital sources should be able to operate profitably, sustainably and to provide services to the productive poor on a larger scale in order to reduce poverty. Therefore, there is a relationship between capital structure, financial sustainability and the level of outreach for MFIs. As indicated by Rhyne and Otero as cited in Mohammed (2011) that mix of financing options of MFIs could attract commercial funds, which may in turn contribute to supporting the outreach goals of MFIs. Similarly, Littlefield and Rosenberg 
(2004) indicate that MFIs do not have the depth of outreach that is needed in order to meet the demands of the rural poor. As a result, providing microcredit and services to the rural poor in the developing world involves a major financial commitment, as it is expensive to run rural microfinance projects.

Over the years, the funding structure of MFIs have changed significantly from donor and government funding to largely commercial funding sources. For instance, MFIs operating in rural areas activities were funded by donor and government subsidized projects in the past. As such the productive poor were not paying for credit extended to them and this resulted in the collapse of most of the MFIs at the time. Currently, this is no longer the case as most MFIs are commercially funded aiming to make profit and achieve financially sustainability. This perhaps explains the high lending rate to the productive poor in northern Ghana, which does not help the poor in the alleviation of their poverty. The justification for the high level of interest rate is the argument by MFIs that it is costly to identify and grant credit to the poor, especially the extremely poor. The best financing strategy is one that helps in mobilizing more financial resources with which the productive poor can be assisted (Mohammed, 2011 cited in Zeller \& Johanssen, 2016).

Although there are several sources of funding for MFIs including equity, grants, deposits, debt sources, a number of studies indicate that equity sources are ideal for sustained operations and outreach. Studies such as Bogan (2012), Omondi (2014), and Cull et al. (2011) noted that if equity sources of capital constitute majority of an MFI capital structure then there is the possibility of reaching out to a greater number of the poor on a consistent basis and the possibility of charging moderate interest to the poor. As a result, Bogan (2012) found causal evidence to support the assertion that the use of grants drives down operational self-sufficiency as funding source for MFIs.

In order to address the market failure which is brought about by the poor who are generally excluded from the financial services sector of most economies by traditional banks and in particular, developing economies in a sustainable manner, Otero (1999) indicates that an MFI must access equity funds to finance their lending portfolios, allowing them to dramatically increase the number of poor people they can reach. This position is supported by Mohammed (2011), who indicates that adequate financing of microfinance, thus offers the potential for a selfpropelling cycle of sustainability and massive growth, whilst providing a powerful impact on the lives of the poor, and even the extremely poor. Thus, a combination of adequate capital and developing technical capacity of MFIs provides a platform for MFIs sustainability and outreach.

In line with the life cycle theory, at the formative stages, most MFIs cannot recover the initial social cost, ultimately implying they cannot deliver their services to the poor, and so a well-established capital structure helps MFIs enhance their financial sustainability to reach out to the poorer communities (Mohammed, 2011). Navajas et al. (as cited in Mohammed, 2011), argued that there is a danger that microfinance may siphon funds from other projects that might better help the poor. Similarly, Barr (2005) also questions the ability of MFIs to achieve the desired outreach level if the capital structure does not support self-sufficiency. As a result, Kiphoech and Muturi (2014) found in their studies that the number of borrowers, capital adequacy and branch network had the greatest influence on the performance of MFI and Ahmed (Year) (as cited in Mohammed, 2011) indicates that if the MFIs resort to the debt sources of capital and thus, borrow at a rate close to market rate of interest, then the effort to increase outreach by including the poorest and reach financial viability as well, may become difficult. There is therefore a relationship between the capital structure, sustainability, and outreach of MFIs.

\subsection{Geographical Coverage and Outreach of MFIs in Ghana}

MFIs in Ghana use several instruments to achieve the ultimate goal of alleviating poverty in order to improve the livelihood of the financially excluded in society. However, most MFIs are geographically located in urban centers across the country where the population is dense. This is of particular concern to the argument that MFIs do not serve the poor. As indicated by Mohammed (2011), one of the key roles microfinance has to play in development is to pursue their social mission, which is, bringing access to financial services to the poor, to those who are neglected by the formal banking sector. The traditional commercial banks will usually target customers who can provide a collateral security for a loan but the poor do not have assets that would serve as collateral, the reason for which they are ignored by the formal financial sector.

Again, the mainstream banks are found in urban centers whilst the majority of the poor in the developing world live in rural areas, where financial services are either very limited or non-existent (Mohammed, 2011; Kimando, Kihoro, \& Njogu, 2012). As a result, if MFIs are to fill this gap in Ghana and in developing countries in general, then they must reach out to the rural poor. This, they can do and at a minimal cost by setting up their offices in rural areas. The practice of setting up branches in rural areas is a recent phenomenon but it is not in strict adherence to the Grameen model, which most MFIs are replicating. A typical Grameen model will setup offices in villages very close to the rural poor where the productive poor can be reached at a lower cost. 
Consequently, Hishigsuren (Year) (as cited in Mohammed, 2011) contends that MFIs do not reach out to the poorest of the poor but rather they are targeting the marginally poor or non-poor. Additionally, most MFIs have no clear rules and criterion to target the poorest of the poor (Mohammed, 2011). This indicates that MFIs are drifting away from their original mission of reaching out to, and serving the poor to profitability and following the lending models of commercial banks that exclude majority of the Ghanaian population. These MFIs also target the richer clients due to the excessive cost of reaching out to the productive poor. In justifying why MFIs charge higher interest rates, Kimando, Kihoro, and Njogu (2012) indicate that it costs much more to make a thousand \$200 loans than to make $\$ 200,000$ loan and thus, to be sustainable, MFIs must charge high interest rates. Similarly, Claessens (2005) argues that high transaction costs, small volumes and high cost of expanding outreach makes it unprofitable to serving the productive poor by MFIs and this explains why traditional banks are geographically located in cities.

The level of outreach indicates the scale of the MFI activities as measured by the number of clients served with different type of instruments such as saving and credit. Depth of outreach measures the type of clients served and their poverty level (Mohammed, 2011). The proxy for depth of outreach used in Cull et al. (2008) is average loan size per GNI per capita, the percentage of women borrowers and percentage of rural clients. MFIs do not have the depth of outreach that is needed to meet the demands of the rural poor. Serving the rural poor in the developing world involves a major financial commitment, as it is expensive to run rural microfinance projects (Mohammed, 2011).

\section{Research Methodology}

This study employed quantitative method for data collection. The reason for the choice of the quantitative method is that it allowed the researcher to test the relationship between some factors and variables in a situation (Bryman $\&$ Bell, 2003). Primary data was used in this research paper. The data was collected with the use of structured questionnaire from a total of 189 experts in the microfinance industry in northern Ghana.

The questionnaire sufficiently addressed the objectives of the study. A descriptive survey technique was employed in this research paper because of its ability to access information regarding current status of a phenomena and the description of "what exists" with respect to situational variables in order to explain the relationship between and among variables (Kimando, Kihoro, \& Njogu, 2012). This method is very suitable for the gathering and collection of broad data.

The population of the study comprised 360 managers and staff of all the MFIs registered and operating in northern Ghana. Northern Ghana is made up of five regions namely Northern Region, Savannah Region, Upper West Region, Upper East Region, and North East Region. However, sampling techniques such as purposive and convenience were used in order to select 189 respondents for the study. "A sample size is a set drawn from the population" (Keller, 2009, p. 5). Thus, the sample size for this study was determined using formula for sample size determination by Adanza (1995).

$$
\text { That is: } n=\frac{N}{1+N e^{2}}
$$

Where: $\mathrm{n}=$ sample size, $\mathrm{N}=$ total population, $\mathrm{e}=$ margin of error; $\mathrm{n}=360 / 1+(0.05) 2(360)=189$, therefore, a minimum of about 189 respondents is desired for this study. In this regard, the study comprised of a sample of at least 189 respondents for the study made up of managers and operations staff of MFIs in northern Ghana.

The questionnaire was distributed to respondents through personal meetings with all managers and staff in all MFIs that were studied across the three northern regions of Ghana. The study employed the services of two research assistants in the data collection process. The services of the research assistants were fully budgeted for. The research assistants were adequately trained before the data collection process and were also guided during data collection. Statistical Package for Social Sciences (SPSS) software was used by the researcher in analyzing the data. This package is widely known and accepted for its ability to handle large amounts of data effectively and efficiently. The researcher used tables to present data with various affiliations such as gender, frequency, percentages, mean and standard deviation among others.

\section{Presentation of Results}

In the course of the study the researcher observed that using a combination of descriptive statistics and Spearman multiple correlations approach were techniques that would facilitate the achievement of the objective of the study. Spearman multiple correlation was applied in examining whether a relationship exists between the geographical coverage of MFIs in northern Ghana and their financial sustainability and outreach. The Spearman correlation results indicated that there was a positive relationship of 0.5434 between geographical coverage and financial sustainability and 0.0418 between geographical coverage and outreach from the point of view of managers and 
operations staff surveyed in northern Ghana. This can be seen in Table 1. The results show a positive relationship between geographical coverage and financial sustainability, and outreach in the view of the respondents.

Table 1. Correlation matrix

\begin{tabular}{lccc}
\hline & Geographical coverage & OUTREACH & Financial sustainability \\
\hline Geographical coverage & 1 & & \\
OUTREACH & 0.0418 & 1 & 1 \\
Financial sustainability & 0.5434 & 0.0934 & 1 \\
\hline
\end{tabular}

From Table 1, it can be seen that correlation value between geographical coverage and outreach in the respondents' view is quite low (0.0418) suggesting no correlation and correlation between geographical coverage and financial sustainability but quite high at 0.5434 , indicating a strong correlation between geographical coverage and financial sustainability. The analysis of variance is shown in Table 2. From the ANOVA, there is a statistically significant relationship between geographical coverage and outreach, and financial sustainability since $\alpha=0.05>0.0029$. $\mathrm{F}(179)=6.0307$, SS Regression is the variation explained by the regression line; SS Residual is the variation of the dependent variable that is not explained.

Table 2. Analysis of Variance (ANOVA) of geographical coverage, financial sustainability of MFIs in Northern Ghana

\begin{tabular}{lccccc}
\hline & $D f$ & $S S$ & $M S$ & $F$ & Significance F \\
\hline Regression & 2 & 11.3830 & 5.6915 & 6.0307 & 0.0029 \\
Residual & 178 & 167.9874 & 0.9437 & & \\
Total & 180 & 179.3704 & & & \\
\hline
\end{tabular}

Table 3 is the coefficient or $p$-value results. It can be observed from the table, that the p-value between geographical coverage and outreach is insignificant at $\alpha=0.05<0.0726$ but statistically significant at $\alpha=0.05>0.0008$ between geographical coverage and financial sustainability. The coefficient of outreach is 0.6412 and that of financial sustainability is 3.5376 .

Table 3. The coefficients of geographical coverage of MFIs in Northern Ghana

\begin{tabular}{lllll}
\hline & Coefficients & Standard Error & $t$ Stat & $P$-value \\
\hline Intercept & 4.3105 & 2.6416 & 1.6318 & 0.1045 \\
OUTREACH & 0.6412 & 0.7173 & -0.8939 & 0.0726 \\
Financial sustainability & 3.5376 & 0.1570 & 3.4247 & 0.0008 \\
\hline
\end{tabular}

\subsection{Discussion of Descriptive Result}

An assessment of a number of clients served by MFIs in northern Ghana suggested that the market was fast growing and the ability to get closer to clients in order to serve the productive poor was critical in MFIs' operations and the achievement of sustainability and outreach levels.

Table 4. Analysis of clients served and period of MFIs operations in the opinion of respondents

\begin{tabular}{|c|c|c|c|c|}
\hline Descriptive & client number before & client number after & Period of org. in operation & worker experience \\
\hline Mean & 1.74 & 4.62 & 4.22 & 1.67 \\
\hline Standard Error & 0.05 & 0.07 & 0.09 & 0.08 \\
\hline Median & 2 & 5 & 5 & 1 \\
\hline Mode & 2 & 5 & 5 & 1 \\
\hline Standard Deviation & 0.6446 & 0.8896 & 1.1670 & 1.0104 \\
\hline Sample Variance & 0.4155 & 0.7914 & 1.3620 & 1.0209 \\
\hline Kurtosis & -0.6918 & 6.9185 & 0.5161 & 3.3142 \\
\hline Range & 2 & 4 & 4 & 4 \\
\hline Minimum & 1 & 1 & 1 & 1 \\
\hline Maximum & 3 & 5 & 5 & 5 \\
\hline Count & 181 & 181 & 181 & 181 \\
\hline
\end{tabular}


Table 4 indicates that MFIs, by the end of their first year of operations, had a mean score of 1.74 with respect to the number of clients served. However, the current number of clients served by MFIs had a mean score of 4.62. Linking the mean scores (1.74 and 4.62) to the number of years the MFIs have operated in northern Ghana indicate a mean score of 4.22. Similarly, MFIs worker experience also has a mean score of 1.67. This implies that there is a consistency in growth rates of clients currently to the number of years of an MFI's operation, which is also linked directly to the level of experience of the work force. This further means that as MFI workers get experience on the job, they are able to grow client numbers thereby enhancing outreach and sustainability in the operations of the MFIs.

The application of Spearman multiple correlation suggests that there is a significant positive relationship between geographical coverage of MFIs and their sustainability and outreach levels. However, in addition, the respondents were assessed on factors they believed influenced the geographical location of MFIs in northern Ghana. As indicated in Table 5, poverty reduction constituted $86(47.5 \%)$ of the responses.

Table 5. Factors believed by respondents to influence the geographical location of MFIs in Northern Ghana

\begin{tabular}{lcc}
\hline & Frequency & Percent \\
\hline Poverty reduction & 86 & 47.5 \\
Close to the poor clients & 20 & 11.0 \\
Close to the rich clients & 4 & 2.2 \\
Close to where there is population & 62 & 34.3 \\
I am not sure & 9 & 5.0 \\
Total & 181 & 100.0 \\
\hline
\end{tabular}

On the contrary, 62 (34.3\%) of the managers and operational staff believed that MFIs are located close to where there is high population. This means that MFIs can reach out many clients, if they are located in areas where the population is high. MFIs will serve many poor clients in a densely populated area than less populated areas and this may reduce the costs of reaching the productive poor in order to reduce poverty. As shown in the Table 5, reducing poverty and locating offices near heavily populated areas accounted for about $82 \%$ of the total responses.

On whether MFIs in northern Ghana received donor funding, 59 (32.6\%) indicated that they received donor funding. However, the majority of the respondents 122 (67.4\%) indicated that MFIs did not receive donor funding. This means that most of the MFIs studied operated with equity funding from shareholders and debt capital from debt holders. This is therefore consistent with the main objective of this study which uncovered that there was a significant positive relationship between capital structure and financial sustainability from the point of view of managers and operation staff surveyed in northern Ghana of 0.609 with equity capital contributing up to $52 \%$ of the relationship.

Table 6. Respondents perception of how MFIs can sustain their operations in Northern Ghana

\begin{tabular}{lcc}
\hline & Frequency & Percentages \\
\hline Profit & & 59 \\
Yes & 107 & 40.9 \\
NO & 74 & 100 \\
Total & 181 & 56.4 \\
Capital from Owners & & 43.6 \\
Yes & 102 & 100 \\
No & 79 & 40.9 \\
Total & 181 & 59 \\
Borrow from Banks & & 100 \\
Yes & 74 & 1.7 \\
No & 107 & 98.3 \\
Total & 181 & 100 \\
Cannot Sustain Operation & & \\
Yes & 3 & 178 \\
No & 181 & \\
Total & & \\
\hline
\end{tabular}


An assessment of how MFIs in northern Ghana can sustain their operations reveals that 107 (59.1\%) of the respondents indicated that operations were profitable. A total of $74(40.9 \%)$ of the respondents rather indicated that their operations will be sustained by borrowing from the banks. A total number of $102(56.4 \%)$ of the respondents indicated that their operations will be sustained by capital contribution from equity owners. On the whole, $178(98.3 \%)$ of the respondents are sure that MFIs in northern Ghana can sustain their operations since the majority of these MFIs are operating without relying on donor funding and support. This is shown in Table 6.

Table 7 is the frequency distribution of geographical coverage of MFIs in the northern regions of Ghana. A total of $157(86.7 \%)$ of the respondents indicated that the place of locating the office of MFIs influenced the client numbers of these MFIs compared with 24 (13.3\%), which indicated that the place of office of an MFI does not have any impact on client numbers. This implies that locating an office of MFIs close to where many productive poor can be reached reduces the cost of outreach and influence the sustainability and outreach levels of MFIs. This is shown in Table 7.

Table 7. Frequency distribution on geographical coverage of MFIs in the view of respondents

\begin{tabular}{|c|c|c|c|}
\hline & Responses & Frequency & Percentages \\
\hline \multirow{3}{*}{$\begin{array}{l}\text { Does the place of location of your office have impact on your clients' } \\
\text { numbers? }\end{array}$} & Yes & 157 & 86.7 \\
\hline & No & 24 & 13.3 \\
\hline & Total & 181 & 100 \\
\hline \multirow[t]{3}{*}{ Does your firm have branches in other parts of the region you operate? } & Yes & 126 & 69.6 \\
\hline & No & 55 & 30.4 \\
\hline & Totals & 181 & 100 \\
\hline \multirow[t]{4}{*}{ Are your branches or offices located in cities in the region you operate? } & Yes & 106 & 58.6 \\
\hline & No & 75 & 41.4 \\
\hline & Total & 181 & 100 \\
\hline & Yes & 30 & 16.6 \\
\hline \multirow{2}{*}{$\begin{array}{l}\text { Do your donors tell you where your offices should be located in either } \\
\text { cities or rural areas? }\end{array}$} & No & 151 & 83.4 \\
\hline & Total & 181 & 100 \\
\hline
\end{tabular}

Most of the MFIs covered in this study had operational presence in other parts of the regions rather than the regional capitals. For example, 126 (69.6\%) of the respondents indicated that their MFIs had operational presence throughout the regions as compared to only $55(30.4 \%)$ of the respondents who indicated that their MFIs did not have operational presence throughout the regions they operated. This is shown in Table 7. This implies that the wider the scope of coverage of MFIs in northern Ghana the greater the outreach level that will be achieved as indicated in Table 7 and ultimately this will enhance the sustainability of MFIs.

Majority of the MFIs indicated that their branches or offices were located in cities as well as rural areas. A total of $106(58.6 \%)$ of the respondents indicated that their offices were not just located in cities but had operational presence in rural areas as well, which meant that MFIs were able to reach the productive poor at a reasonable cost and that, in turn, enhanced sustainability and outreach levels. On the other hand, 75 (41.5\%) of the respondents maintained that their MFIs operated in rural areas of the five northern regions thereby reducing the cost of outreach and improving sustainability and outreach levels. This is shown in Table 7.

A total of 151 (83.4\%) of the respondents were of the view that donors do not tell management of MFIs where to locate their offices (for instance, rural areas or cities) compared to the 30 respondents ( $16.6 \%$ who indicated that their donors tell them specifically, areas to locate their offices so as to reach the productive poor. This also implies that the cost of reaching the productive poor will reduce, increase outreach levels thereby enhancing the sustainability of MFIs. This also means that the possibility of mission drift will be guarded against so that MFIs are focused on their social mission of reducing poverty among the productive poor. This is shown in Table 7. This response is also consistent as very few of the MFIs studied received donor funding and support in their operations. This means that for outreach and sustainability to be achieved, the scope of MFIs' operations matters, particularly in rural areas, must be given a priority and expanded. Most MFIs operating in cities do not really serve the productive poor but rather serves the average or richer clients.

The descriptive statistics, thus, confirm the Spearman multiple correlation score of 0.395 which indicated a statistically significant positive relationship between geographical coverage and MFIs sustainability and outreach from the point of view of managers and operation staff in northern Ghana. Based on the above results, the study 
rejects the null hypothesis (H1o), which suggests that there is no statistically significant relationship between geographical coverage of an MFI and sustainability and outreach from the point of view of managers and operational staff in northern Ghana. Thus, the findings of the study are in favour of the alternative hypothesis (H1a), which maintains that, there is a statistically significant relationship between geographical coverage of an MFI and sustainability and outreach from the point of view on managers and operational staff in northern Ghana.

\subsection{Discussion of Results}

The findings of the study are supported by Kimando, Kihoro and Njogu (2012) who found that the number of clients served and financial coverage influenced the sustainability and outreach of MFIs in the Murang'a Municipality in Kenya. The findings are further supported by Mohammed (2011) who contends that the level of outreach of MFIs indicate the scale of the MFI activities as measured by the number of clients served with different types of instruments such as saving and credit. Mohammed (2011) further contends that MFIs do not reach the poorest of the poor but rather they are reaching the marginally poor or non-poor. That was particularly so because most offices of MFIs are located at the regional and district capitals and very few or no offices located in the villages where the poorest of the poor live.

MFIs are less dependent on donor funds in northern Ghana, which is supported by Bogan (2012) who contends that the use of grants or donor support drives down operational self-sufficiency of MFIs. As a result, MFIs in northern Ghana should focus on equity funding to be a greater proportion of its capital structure in relation to debt and donor funding as this will enhance sustainability and improve outreach.

\section{Conclusions and Recommendations}

The study uncovered a statistically significant positive relationship between geographical coverage and financial sustainability and outreach from the point of view of managers and operational staff of MFIs in northern Ghana using Spearman's correlation. The use of descriptive statistics revealed that geographical coverage of an MFI influenced its sustainability and outreach with particular reference to the number of clients served, location of offices or branches, scope of coverage, and to the extent that MFIs did not depend so much on donor funding and support in the views of the respondents.

Based on the findings of the study the following policy recommendations are made:

\subsection{Merger of MFIS}

It is clear from the study that for MFIs to be able to serve a greater number of the poor clients, they (MFIs) should consider merging in their operations in order to become efficient and effective in the delivery of services to their clients. Merger will increase MFIs' capital base and by extension increase their lending capacity to the poor. This will improve upon the profitability and sustainable operations. The Bank of Ghana should facilitate the merger process since most MFIs are not meeting the revised minimum capital requirement needed for operation as an MFI.

\subsection{Increase Branch Offices in Rural Areas in Northern Ghana}

A total of $87 \%$ of the respondents indicated that locating offices close to the productive poor reduces the costs of outreach and greatly influence the sustainability and outreach levels of MFIs in northern Ghana. However, most MFIs had majority of their offices in urban areas in northern Ghana. Based on this outcome the researcher recommends that MFIs should open more branches in the rural areas where the poorest of the poor live. This will reduce the cost of outreach and enable MFIs serve the poor rather than serving only the average or perhaps the richer clients.

\section{Recommendations for Further Research}

Similar investigation should be conducted in all the other administrative regions of Ghana since this particular study only focused on regions in northern Ghana and therefore could be described to some extent as limited in scope.

\section{References}

Aveh, F. K. (2011). An evaluation of the performance of MFIs in Ghana. DBA thesis, Bradford University, UK.

Ayayi, A., \& Sene, M. (2010). What drives microfinance institution's financial sustainability. The Journal of Developing Areas, 44(1), 303-324. https://doi.org/10.1353/jda.0.0093

Bakhtiari, S. (2006). Microfinance and poverty reduction: Some international evidence. International Business and Commerce Research Journal, 5(12), 65-71. https://doi.org/10.19030/iber.v5i12.3550

Bayar, Y. (2013). Future of microfinance in the light of recent crises in major microfinance Markets, Social Business, 3(3), 243-249. https://doi.org/10.1362/204440813X13778729134363 
Bogan, V. (2012). Capital structure and sustainability: An empirical study of microfinance Institutions. The review of economics and statistics, 94(4), 1045-1058. https://doi.org/10.1162/REST_a_00223

Bogan, V., Johnson, W., \& Mhlanga N. (2007). Does capital structure affect the financial sustainability of microfinance institutions? Cornell University, 454 Warren Hall, Ithaca, NY 14853.

Britzelmaier, B., Kraus, P., \& Xu, Y. (2013). Microfinance institutions in China: Development and challenges to their sustainability. Strategic Change, 22, 67-78. https://doi.org/10.1002/jsc.1922

Cull, R., Demirguc-Kunt, A., \& Morduch, J. (2007). Financial performance and outreach: A global analysis of leading microbanks. Economic Journal, 117, 107-133. https://doi.org/10.1111/j.1468-0297.2007.02017.x

Demirguc-Kunt, A., and Klapper L. (2012). Measuring financial inclusion: The global findex database. The World Bank Development Research Group, Policy Research Working Paper 6025. https://doi.org/10.1596/18139450-6025

Ganka, D. (2010). Financial sustainability of rural microfinance institutions in Tanzania. $\mathrm{PhD}$ thesis, University of Greenwich, Australia.

Hartarska,V., \& Nadolnyak, D. (2007). Do regulated microfinance institutions achieve better sustainability and outreach? Cross-country evidence, 39, 1207-122. https://doi.org/10.1080/00036840500461840

Hulme, D., \& Mosley, P. (1996). Finance against poverty: Effective institutions for lending to small farmers and micro-enterprises in developing countries (Vol. 1). London: Routledge. https://doi.org/10.1016/S0305$750 \mathrm{X}(98) 00021-7$

Kimando, L. N., Kihoro, J. M., \& Njogu, G. W. (2012). Factors influencing the sustainability of microfinance institutions in Murang's Municipality. International Journal of Business and Commerce, 1(10), 21-45.

Kindie, B. A. (2012). Financial sustainability of microfinance institutions in Ethiopia. European Journal of Business and Management, 4(15), 1-11. https://doi.org/10.7176/EJBM

Kipkoech, J. B., \& Muturu, W. (2014). Determinants of financial performance of microfinance institutions in Kenya: A case of institutions in Nakuru town. International Journal of Accounting and Financial Management, 4(6), 1-16.

Kyereboah, A. (2007). The impact of capital structure on the performance of microfinance Institutors. Journal of Risk Finance, 8, 56-71. https://doi.org/10.1108/15265940710721082

Leikem, K. (2012). Microfinance: A tool for poverty reduction? Honors program at the University of Rhode Island. Senior Honors Project. Retrieved from http://digitalcommons.uri.edu/srhonorsprog/300

Madajewicz, M. (2011). Joint liability versus individual liability in credit contracts. Journal of Economic Behaviour and Organization, 77, 107-123. https://doi.org/10.1016/j.jebo.2008.01.007

Mersland, R., \& Strom, R. (2009). Performance and governance in microfinance institutions. Journal of Banking and Finance, 33, 662-669. https://doi.org/10.1016/j.jbankfin.2008.11.009

Mohammed, S. (2011). Financing strategies, financial sustainability and outreach of SACCOs in Uganda. Master thesis, Makerere University, Uganda.

Nurmakhanova, M., Kretzschmar, G., \& Fedhila, A. (2015). Trade -off between financial sustainability and outreach of microfinance institutions. Eurasia Business and Economics Society, 5, 231-250. https://doi.org/10.1007/s40822-015-0016-7

Nyamsogoro, G. D. (2010). Financial sustainability of rural microfinance institutions in Tanzania. PhD thesis, University of Greenwich, Australia.

Omondi, B. E. (2014). The relationship between funding structure and financial performance of microfinance institutions in Kenya. MBA thesis, University of Nairobi, Kenya.

Paxton, J. (2003). A poverty outreach index and its application to microfinance. Economic Bulletin, 9(2), 1-10.

Quayes, S. (2012). Depth of outreach and financial sustainability of microfinance institutions. Applied Economics, 44(26), 3421-3433. https://doi.org/10.1080/00036846.2011.577016

Salifu, I., \& Ayeboafo, B. (2019). Relationship between financial regulation and microfinance institutions sustainability and outreach in northern Ghana. European Journal of Business and Management, 11(25), 97112. https://doi.org/10.7176/EJBM/11-25-10

Salifu, I., Mahama, M., \& Dawuni, M. (2019). Evaluation of factors influencing the sustainability and outreach of 
microfinance institutions in northern Ghana. Research Journal of Finance and Accounting, 10(16), 141-155. https://doi.org/10.7176/RJFA/10-16-16

Schreiner, M. (2002). Aspect of outreach: A framework for discussion of social aspect of microfinance. Journal of International Development, 14, 591-603. https://doi.org/10.1002/jid.908

Tehulu, T. A. (2013). Determinants of financial sustainability of microfinance in East Africa. European Journal of Business and Management, 5(17), 152-158. https://doi.org/10.7176/EJBM

Thapa, B., Chalmers, J., Taylor, W., \& Conroy, J. (1992). Banking with the poor, report and recommendations. prepared by lending Asian banks and non-governmental organizations, Brisbane, Australia.

Woller, G., Dunford, C., \& Woodworth, W. (1999). Where to microfinance. International Journal of Economic Development, 1, 29-64.

Yunus, M. (1999). Banker to the poor-micro-lending and the battle against world poverty. New York, Public Affairs.

Zeller, M. (2001). Solidarity groups: Reaching poor clients with high repayment rates. Focal Point for Microfinance, 2(1), 4-6.

\section{Copyrights}

Copyright for this article is retained by the author(s), with first publication rights granted to the journal.

This is an open-access article distributed under the terms and conditions of the Creative Commons Attribution license (http://creativecommons.org/licenses/by/4.0/). 